\title{
Effect of seeding rate of Crotalaria (Crotalaria juncea L.) on Green Manure Yield and Nitrogen Prodution in Upland Soil
}

\author{
Hyeoun-Suk Cho*, Ki-Yeung Seong, Tea-Sun Park, Myung-Chul Seo, Mi-Hyang Kim, \\ Hang-Won Kang, and Hye-Jin Lee \\ Crop Environment Research Division, National Institute of Crop Science (NICS), \\ RDA, 125 Suinro Gwonseon-gu, Suwon, Gyeonggido, 441-857, Korea
}

(Received: November 4 2013, Accepted: November 14 2013)

\begin{abstract}
We researched nitrogen and green manure yield of crotalaria by seeding rate; $50,60,70,80,90 \mathrm{~kg} \mathrm{ha}^{-1}$ in upland soil to find out crotalaria's optimal seeding rate. Crotalaria's plant height and number of leaves increased when the harvest time was later regardless of its seeding rate. Its nitrogen content of above-ground part was $19.8 \mathrm{~g} \mathrm{ha}^{-1}$, and $\mathrm{C} / \mathrm{N}$ ratio was 22.5 . The highest nitrogen content $\left(50.3 \mathrm{~g} \mathrm{~kg}^{-1}\right)$ was found in flowers part, followed by its leaves, roots and stems. The green manure yields of crotalaria increased when the harvest time was later. The green manure yield of crotalaria was biggest in $50 \mathrm{~kg} \mathrm{ha}^{-1}$ which was low in seeding rate. It tended to decrease when the seeding rate was higher, and the nitrogen yield had the same tendency. Therefore, the appropriate seeding rate was $50 \mathrm{~kg} \mathrm{ha}^{-1}$ and the time for application to soil was considered to be the flowering stage.
\end{abstract}

Key words: Crotalaria, Green manure crops, Nitrogen yield
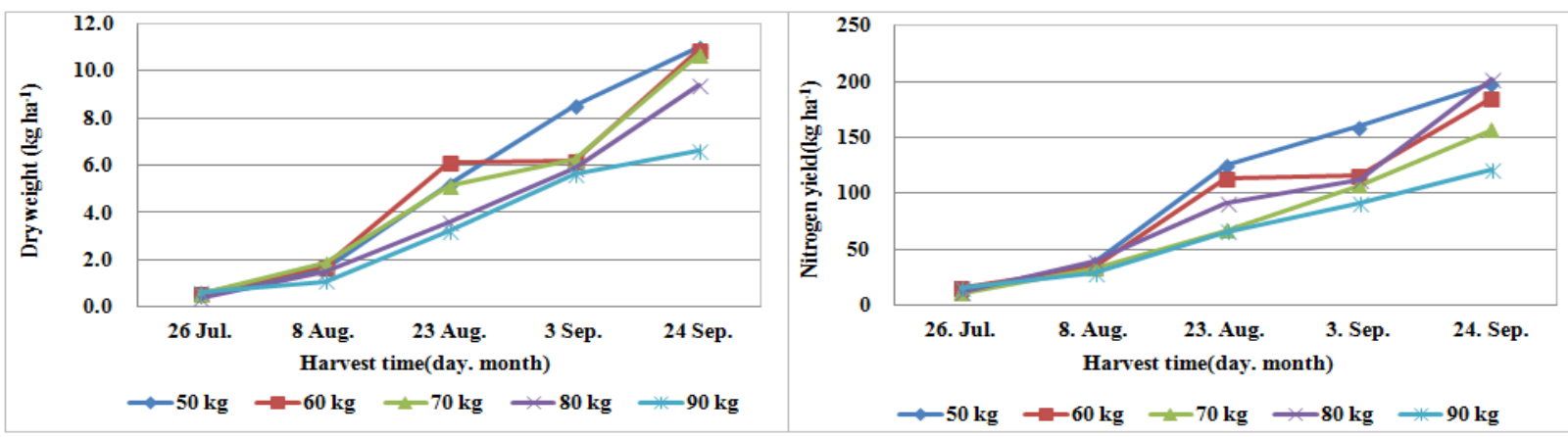

Crotalaria's green manure yield and nitrogen yield were biggest in $50 \mathrm{~kg} \mathrm{ha}^{-1}$, and the yield tended to decrease when the seeding rate was higher. 


\section{Introduction}

클로탈라리아 (Crotalaria juncea L.)는 인도가 원산지인 일년생 작물로 옛날부터 섬유 또는 녹비용으로 재배되어 왔 다. 이 작물은 추위에 약하기 때문에 우리나라에서는 6월에 파 종하여 11월까지 생육이 가능한 여름용 작물이다 (Treadwell and Alligood, 2007). 클로탈라리아는 초장이 $2 \mathrm{~m}$ 이상 자 라는 콩과작물로 뿌리에서 근류균에 의한 질소고정으로 식 물체의 질소함량이 $2.1 \sim 3.1 \%$ 로 높고 $\mathrm{C} / \mathrm{N}$ 율은 25 미만으로 낮아 녹비로 이용 가치가 높은 작물이다 (Chaudhury et al., 1978; Daimon and Kotoura, 2000; RDA, 2009; Treadwell and Alligood, 2007). 또한 클로탈라리아는 초기생육이 빨라 짧 은 생육기간에 많은 녹비수량이 생산되고 사토, 양토, 식양 토 등 다양한 토양에서도 생육이 가능할 뿐만 아니라 노지, 시설재배지 등 재배조건에 관계없이 잘 자라는 특성을 가지 고 있다. 외국에서는 1930년대부터 클로탈라리아에 대한 토 양질 개선, 질소고정에 의한 양분 공급, 유기물 공급 등에 대 한 연구 (Cook and White, 1996; Treadwell and Alligood, 2007)들이 진행되어 왔으나 우리나라는 2005년부터 관심을 가지면서 녹비작물로 이용하기 위한 연구들이 시작되었다. 클로탈라리아는 식량작물보다는 원예작물과의 작부체계가 더 다양하여 시설하우스나 노지 원예작물인 오이, 당근, 딸 기, 참외, 상추, 배추 등을 중심으로 많은 연구들이 이루어 져 왔다 (Choi et. al., 2011; Lee et. al., 2008; Lee et. al., 2012; Lim et. al., 2012; RDA, 2009). 원예작물은 고온기인 여름동안 약 2 3개월의 휴지기를 갖는데 이 시기에 클로탈 라리아를 재배하여 토양에 환원하면 후작물에 비료공급, 유 기물 시용, 토양 특성개선, 병해충 억제 등의 효과를 얻을 수 있다. 시설재배지에서 클로탈라리아를 여름 휴한기에 재 배하여 얻은 건초수량은 7.9 ton ha $^{-1}$ 이었고, 이 때 질소는 $121 \mathrm{~kg} \mathrm{ha}^{-1}$, 인산은 $16.8 \mathrm{~kg} \mathrm{ha}^{-1}$, 칼리는 $214 \mathrm{~kg} \mathrm{ha}^{-1}$ 의 양 분이 고정되었다. 클로탈라리아 초장은 파종량이 증가될수 록 감소되었으며, 시설재배지에서 클로탈라리아를 녹비로 이 용하여 화학비료 대비 $94.6 \%$ 의 토마토 수량을 얻었으며 배 추와 상추에서는 질소비료 $50 \%$ 를 절감 하였다 (RDA, 2009). 또한 토양 내 뿌리혹선충의 억제 효과가 뛰어난 것으로 알려지 면서 토양 내 선충피해가 큰 딸기, 오이, 참외, 배추 등을 재배 하는 농가에서 많이 이용되고 있다 (Germani and Plenchette, 2005; Orwa et. al., 2009; Wang et. al., 2003; Wang et. al., 2006; Yang et. al., 2011). 현재 농가에서 클로탈라리아
이용시 파종량은 종자회사에서 추천하고 있는 $60 \sim 80 \mathrm{~kg} \mathrm{ha}^{-1}$ 를 사용하고 있다. 그러나 최근 클로탈라리아의 수요 증가 로 종자가격이 상승하고 있어 농가에서는 종자구입에 따른 부담이 가중되고 있다. 따라서 본 연구는 여름용 녹비작물 로 이용 가치가 높은 클로탈라리아의 파종량에 따른 생육, 수량 및 질소생산량 등의 검토를 통해 적정 파종량을 구명 하고자 하였다.

\section{Materials and Methods}

본 시험은 수원 소재 국립식량과학원 작물환경과의 밭 토양에서 2012년 6월 12일부터 9월 25일까지 수행되었으며 시험 전 토양특성은 Table 1과 같았다.

클로탈라리아 (crotalaria juncea L.)는 수입종자를 구매 하여 사용하였고 파종량은 ha당 $50,60,70,80,90 \mathrm{~kg}$ 을 $30 \mathrm{~cm}$ 간격으로 6 월 12 일에 줄뿌림 하였다. 시험구 배치는 난괴법 3 반복을 사용하였으며, 화학비료는 질소, 인산, 칼 리 모두 무시용 하였다. 클로탈라리아의 생육 및 수량은 농 촌진흥청 농업과학기술연구 조사분석 기준 (RDA, 2003)에 의거하여 개화기에 식물체의 초장, 주당엽수, 주당마디수와 개화특성을 조사하였고, 수량조사를 위하여 파종 후 40 일부 터 105 일까지 15 일 간격으로 $0.3 \mathrm{~m}^{2}$ 의 식물체를 3 반복으로 수확하여 생체중을 측정한 다음 $50^{\circ} \mathrm{C}$ 에서 48 시간 열풍건조 후 건물중을 측정하였다. 이 때 클로탈라리아의 부위별 수 량과 양분함량을 조사하기 위하여 별도로 $0.15 \mathrm{~m}^{2}$ 의 식물체 를 지상부와 지하부로 나누어 채취하였다. 지상부는 줄기, 잎, 꽃으로 분리하여 무게를 측정하였으며, 지하부 (뿌리)는 물로 세척 후 건조하여 무게를 측정하였다. 이들 식물체 시 료는 $50^{\circ} \mathrm{C}$ 에서 48 시간 동안 열풍건조 한 다음 마쇄하여 분 석용 시료로 사용하였다. 마쇄된 시료는 원소분석기 (LECO CNS-2000)를 이용하여 T-C, T-N, C/N율을 정량하였고, 무기 성분은 분쇄한 시료에 $\mathrm{H}_{2} \mathrm{O}_{2}-\mathrm{H}_{2} \mathrm{SO}_{4}$ 를 첨가하여 습식 분해하여 유도결합플라즈마 (Inductively Coupled Plasma Spectrometer, $\mathrm{GBC} \mathrm{SDS}-270)$ 를 이용하여 무기성분을 측정하였다.

시험토양의 화학적 특성 분석은 작토층 $(10 \mathrm{~cm}$ 층위 $)$ 을 채 취하여 음건한 다음 $2 \mathrm{~mm}$ 체를 통과시켜 조제하였으며 농 촌진흥청 토양 및 식물체 분석법 (NIAST, 2000)에 준하여 $\mathrm{pH}$ 는 토양과 증류수를 $1: 5$ 로 희석, $\mathrm{pH}$ meter를 이용하여 측정하였고, $\mathrm{T}-\mathrm{C}$ 와 $\mathrm{T}-\mathrm{N}$ 은 원소분석기 (Elementary analysis, $\mathrm{LECO} \mathrm{CNS}-2000)$, 치환성양이온과 인산함량은 동시침출법

Table 1. Physiochemical properties of the soil used for the field experiment.

\begin{tabular}{|c|c|c|c|c|c|c|c|}
\hline \multirow{2}{*}{$\begin{array}{c}\mathrm{pH} \\
(1: 5)\end{array}$} & \multirow{2}{*}{$\mathrm{T}-\mathrm{C}$} & \multirow{2}{*}{$\mathrm{T}-\mathrm{N}$} & \multirow{2}{*}{ Avail. $\mathrm{P}_{2} \mathrm{O}_{5}$} & \multicolumn{3}{|c|}{ Exch. cations } & \multirow{2}{*}{$\begin{array}{c}\text { Soil } \\
\text { texture }\end{array}$} \\
\hline & & & & $\mathrm{Ca}$ & $\mathrm{Mg}$ & $\mathrm{K}$ & \\
\hline & $\mathrm{g} \mathrm{kg}^{-1}$ & $\mathrm{~g} \mathrm{~kg}^{-1}$ & $\mathrm{mg} \mathrm{kg}^{-1}$ & - & $\mathrm{nol}_{\mathrm{c}} \mathrm{k}$ & - n & \\
\hline 5.3 & 6.9 & 0.39 & 140 & 3.69 & 1.16 & 0.79 & Loam \\
\hline
\end{tabular}


으로 추출하여 유도결합플라즈마 (Inductively Coupled Plasma Spectrometer, GBC SDS-270)를 이용하여 정량 하였다.

통계분석은 SAS 9.2 버전을 이용하여 클로탈라리아의 생 육 및 수량 등을 $5 \%$ 유의수준에서 Duncan's multiple test 를 수행하였다.

\section{Results and Discussion}

수확시기에 따른 클로탈라리아의 생육 클로탈라리아 는 생육초기에 빠른 성장을 보이는 작물로 식물체는 Fig. 1 과 같이 분지없이 직립으로 빽빽하게 자라며 개화가 시작되 면 노란색 꽃이 위쪽에 달린다. 파종량별 수확시기에 따른 클로탈라리아의 생육은 Fig. 2와 같이 초장은 수확시기가 늦어질수록 증가되어 파종 후 70일까지 급격히 증가하였고 그 후에는 완만하게 증가하였으며 파종량에 따른 차이는 없 었다. 클로탈라리아는 파종 후 55 일에 초장이 $1 \mathrm{~m}$ 에 달하였 다. 주당 엽수는 수확시기가 늦어질수록 계속 증가되었으며 생육초기에는 파종량에 따른 차이를 보이지 않았으나 파종
후 70일부터 파종량 간에 뚜렷한 차이를 보였다. 파종량별로 보면 50 70 kg ha에서 주당엽수가 많았고 $80 \sim 90 \mathrm{~kg} \mathrm{ha}^{-1}$ 에서 적었으며 파종량이 많을수록 감소하는 경향이었다. 클 로탈라리아 파종량이 많아지면 초장은 발달속도가 늦어지 고 줄기의 직경과 마디수가 감소한다는 보고와는 달리 본 연구에서 초장은 파종량에 따른 차이가 미미하였으나 주당엽 수는 파종량이 증가할수록 감소되는 경향을 보였다 (Daimon and Kotoura, 2000; RDA, 2009).

\section{클로탈라리아의 개화기 생육 및 개화특성 클로탈라} 리아의 개화기 생육은 Table 2와 같이 초장은 159 169 cm 로 파종량간에 차이는 없었으나, 주당엽수와 주당마디수는 파종량이 증가할수록 적어지는 경향을 보여 Daimon and Kotoura (2000)의 연구내용과 같은 경향이었다. 개화특성 을 보면 개화소요일수는 50 51일로 짧은 반면 개화기간은 70 72일로 매우 길었으며 꽃길이는 $24.8 \sim 25.6 \mathrm{~cm}$, 꽃수는 주당 4.8 5.3개였다. 클로탈라리아의 개화특성을 보면 개 화소요일수는 짧고 개화기간은 길기 때문에 경관작물로 이용
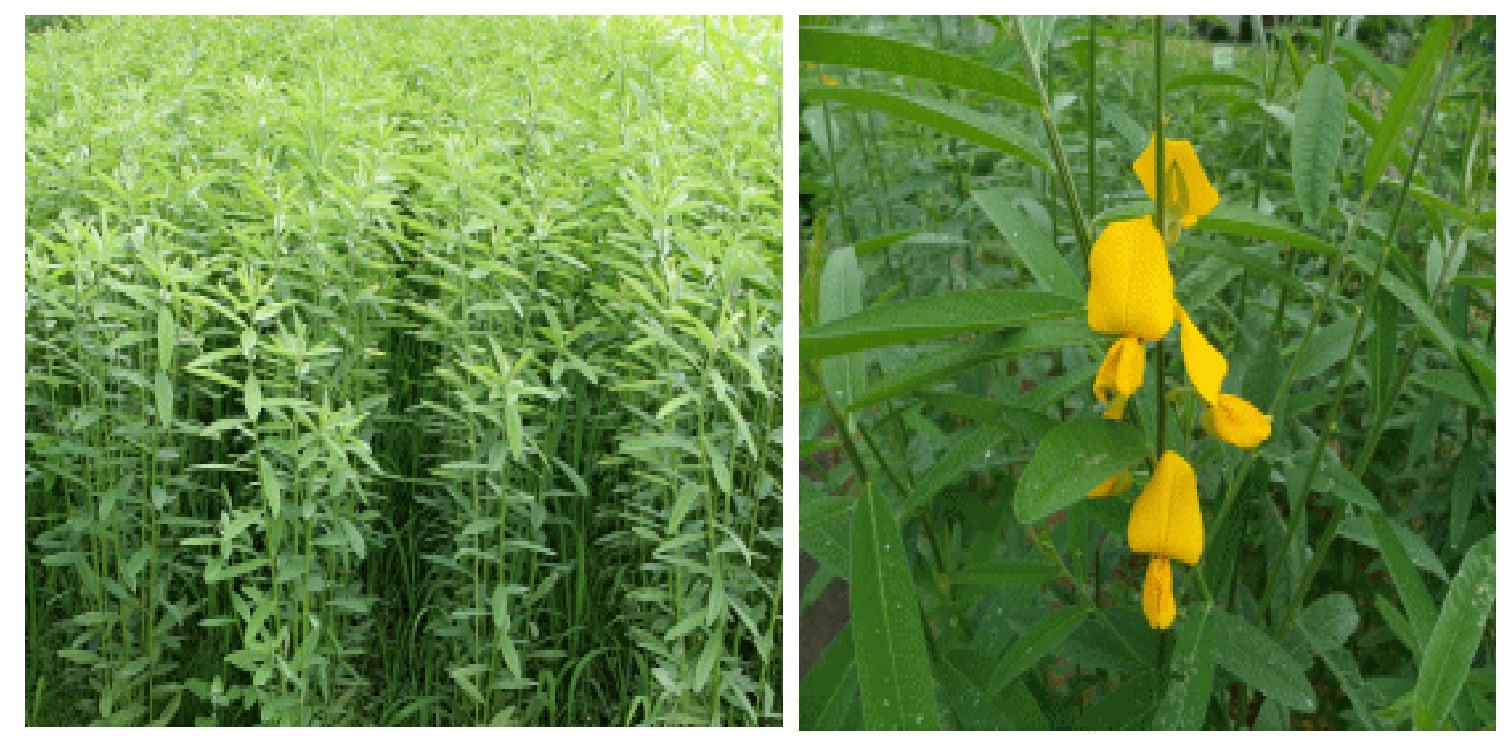

Fig. 1. The picture of before flower (Left) and after flower (Right) of crotalaria in the field.
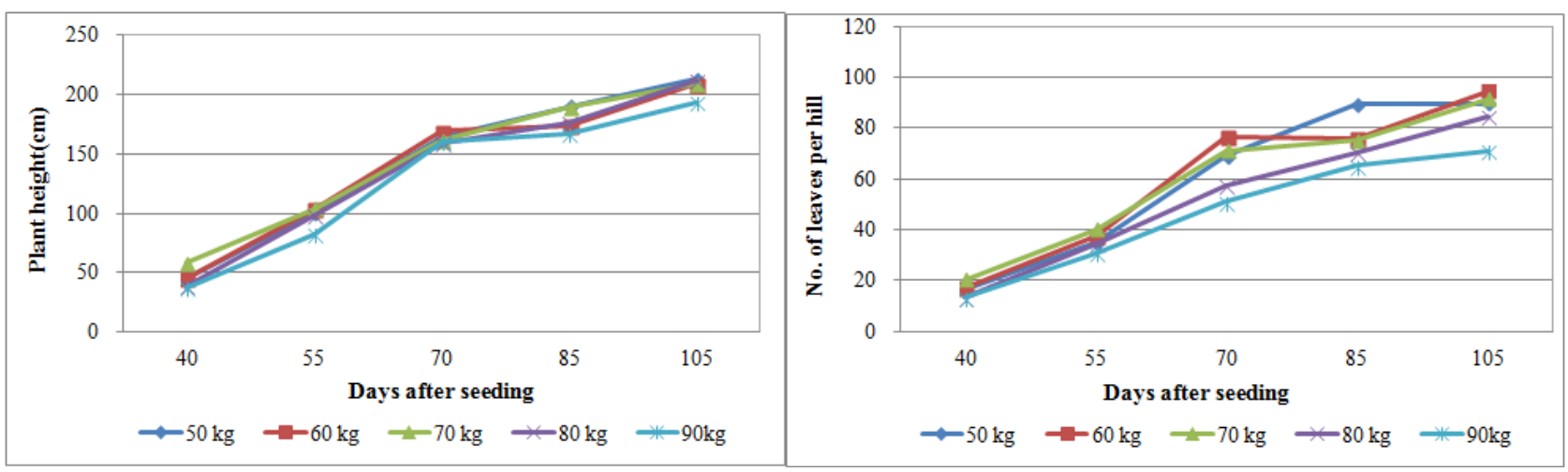

Fig. 2. The changes of plant height(Left) and number of leaves(Right) of crotalaria by the different seeding rate. 
Table 2. The growth and flowering characteristics of crotalaria according to seeding rate during flowering time.

\begin{tabular}{|c|c|c|c|c|c|c|c|}
\hline \multirow[b]{2}{*}{ Seeding rate } & \multirow[b]{2}{*}{ Plant height } & \multirow{2}{*}{$\begin{array}{c}\text { No. of leaves } \\
\text { per hill }\end{array}$} & \multirow{2}{*}{$\begin{array}{c}\text { No. of nodes } \\
\text { per hill }\end{array}$} & \multicolumn{4}{|c|}{ Flowering characteristics } \\
\hline & & & & $\begin{array}{l}\text { No. of days to } \\
\text { flowering }\end{array}$ & $\begin{array}{c}\text { Flowering } \\
\text { period }\end{array}$ & Flower length & $\begin{array}{c}\text { No. of flower } \\
\text { per hill }\end{array}$ \\
\hline & $\mathrm{cm}$ & & & day & day & $\mathrm{cm}$ & \\
\hline $50 \mathrm{~kg}$ & $164 \mathrm{a}\rfloor$ & $69.1 \mathrm{a}$ & $60.7 \mathrm{a}$ & 50 & 70 & $25.6 \mathrm{a}$ & $5.2 \mathrm{a}$ \\
\hline $60 \mathrm{~kg}$ & $169 \mathrm{a}$ & $76.6 \mathrm{a}$ & $57.5 \mathrm{a}$ & 51 & 72 & $24.8 \mathrm{a}$ & $5.0 \mathrm{a}$ \\
\hline $70 \mathrm{~kg}$ & $162 \mathrm{a}$ & $71.1 \mathrm{a}$ & $58.6 \mathrm{a}$ & 50 & 71 & $25.1 \mathrm{a}$ & $5.3 \mathrm{a}$ \\
\hline $80 \mathrm{~kg}$ & $159 \mathrm{a}$ & $57.4 \mathrm{~b}$ & $53.9 \mathrm{~b}$ & 50 & 71 & $25.0 \mathrm{a}$ & $4.8 \mathrm{a}$ \\
\hline $90 \mathrm{~kg}$ & $161 \mathrm{a}$ & $51.0 \mathrm{~b}$ & $50.9 \mathrm{~b}$ & 51 & 70 & $25.4 \mathrm{a}$ & $5.0 \mathrm{a}$ \\
\hline
\end{tabular}

※ Survey day : 2012. 8. 23.

\rfloor Means in a column followed by the same letter are not significantly different at $\mathrm{p} \leq 0.05$ based on Duncan's multiple range test

할 경우 오랜 기간 동안 꽃을 볼 수 있을 것으로 기대된다.

\section{파종량별 수확시기에 따른 클로탈라리아의 녹비수량} 클로탈라리아의 지상부와 지하부 비중은 Fig. 3과 같이 지 상부는 식물체 전체 중 $90 \%$, 지하부는 $10 \%$ 를 차지하였다. Yang et. al. (2011)에 의하면 클로탈라리아의 T/R율이 4.7 로 뿌리비중이 큰 편이라고 하였는데 본 시험에서 보면 클 로탈라리아는 다른 녹비작물에 비하여 뿌리가 길고 굵지만 지상부의 수량이 많기 때문에 식물체 전체를 볼 때 지하부 가 차지하는 비중이 크지 않았다. 수확시기에 따른 클로탈

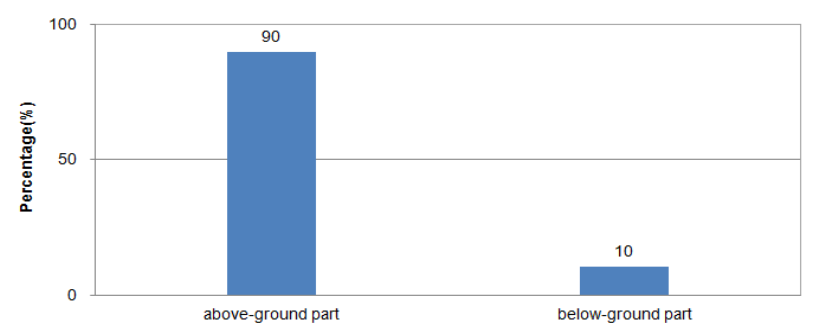

Fig. 3. The percentage of yield of above- and below-ground parts of crotalaria during flowering time.

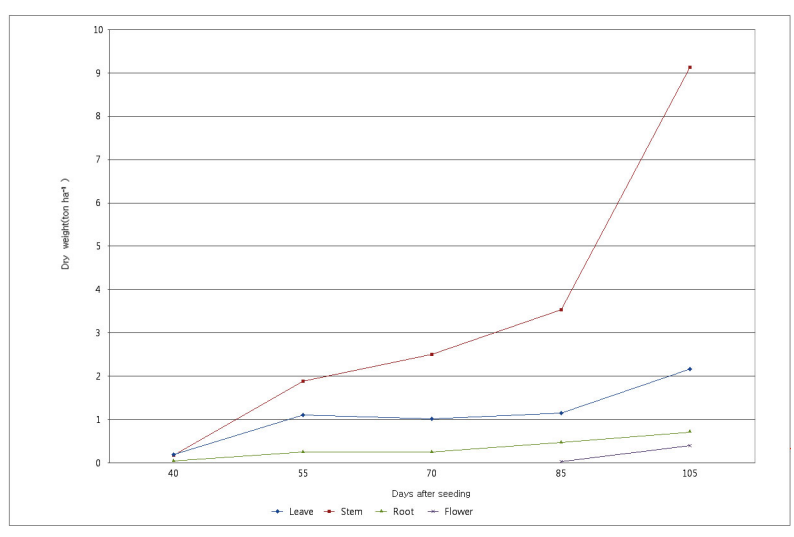

Fig. 4. The dry weight of parts of crotalaria by the different harvesting times.
라리아의 부위별 건물수량은 Fig. 4 와 같이 수확시기가 늦 어질수록 증가하였으며 줄기가 다른 부위에 비하여 월등히 많았다. 수량증가 정도를 보면 줄기에서 가장 급격한 증가 를 보였으며 잎은 파종 후 55 일까지 증가한 다음 일정하였 고 뿌리는 파종 후 105 일까지 완만하게 증가되었다. 줄기의 건물수량이 다른 부위에 비하여 급격하게 증가한 이유는 식 물체의 초장이 길고 줄기는 분지없는 직립형이며 직경은 $5.1 \mathrm{~cm}$ 로 굵어 식물체 중 줄기가 차지하는 비중이 컸기 때 문이며 개화기 이후 식물체의 수분감소가 건물중을 현저하 게 증가시킨 것으로 사료되었다 (Treadwell and Alligood, 2007). 클로탈라리아를 녹비로 토양에 환원 할 경우 토양환 원 시기는 개화기 이후에 환원해도 $\mathrm{C} / \mathrm{N}$ 율이 낮아 분해에는 문제가 없지만 줄기가 단단해져 경운이 어렵기 때문에 줄기 가 단단해지기 전인 개화시 (파종 후 약 50 일 전후)에 이용 하는 것이 좋을 것으로 판단되었다 (Fig. 6 참조).

파종량에 따른 수확시기별 클로탈라리아의 건물수량은 Fig. 5 와 같이 모든 파종량에서 수확시기가 늦어질수록 증 가하였다. 파종량별로 보면 파종 후 55 일까지는 파종량간에 차이가 없었으나 그 후에는 수확시기가 늦어질수록 뚜렷한 차이를 보였다. 수량이 가장 많은 파종량은 $50 \mathrm{~kg} \mathrm{ha}^{-1}$ 이었 으며 파종량이 증가할수록 녹비 건물수량은 점차 감소되어 $90 \mathrm{~kg} \mathrm{ha}^{-1}$ 에서 녹비수량이 가장 적었다. 이는 지상부와 지 하부 수량에서 모두 같은 경향을 보였다. 파종량이 많았던 $90 \mathrm{~kg} \mathrm{ha}^{-1}$ 에서 수량이 적었던 것은 많은 파종량에 따른 식 물체간 양분경합으로 충분히 자라기보다는 연약하게 웃자 랐기 때문으로 판단되었다. 시설하우스나 노지에서 클로탈 라리아를 녹비로 사용 할 경우 토양환원시기를 파종 후 50 일 (개화시 기준) 전후로 하고 있는데 이 때에는 파종량에 관계없이 비슷한 수량을 보이는 반면 수확시기가 개화기 이 후로 늦어지면 파종량이 적을수록 더 많은 녹비가 생산되었 다. 따라서 클로탈라리아를 녹비로 사용 할 경우 현재 사용 하고 있는 60 80 kg ha의 파종량을 $50 \mathrm{~kg} \mathrm{ha}^{-1}$ 로 줄이는 


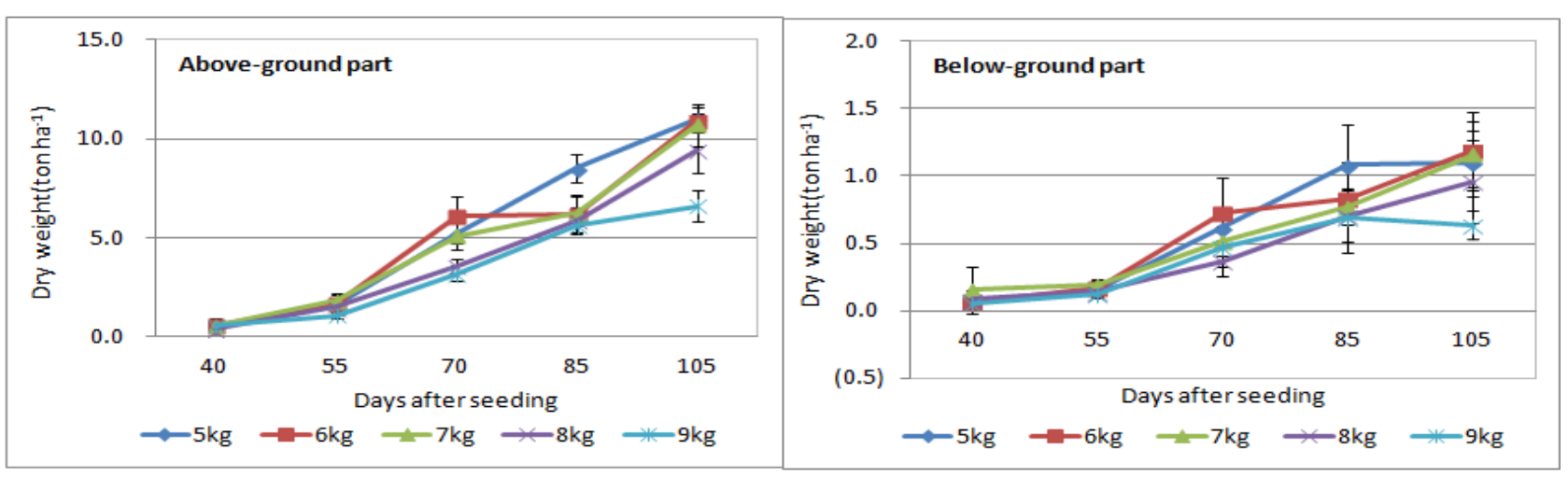

Fig. 5. The changes of dry weight of above- and below-ground parts of crotalaria according to seeding rates and harvesting time.
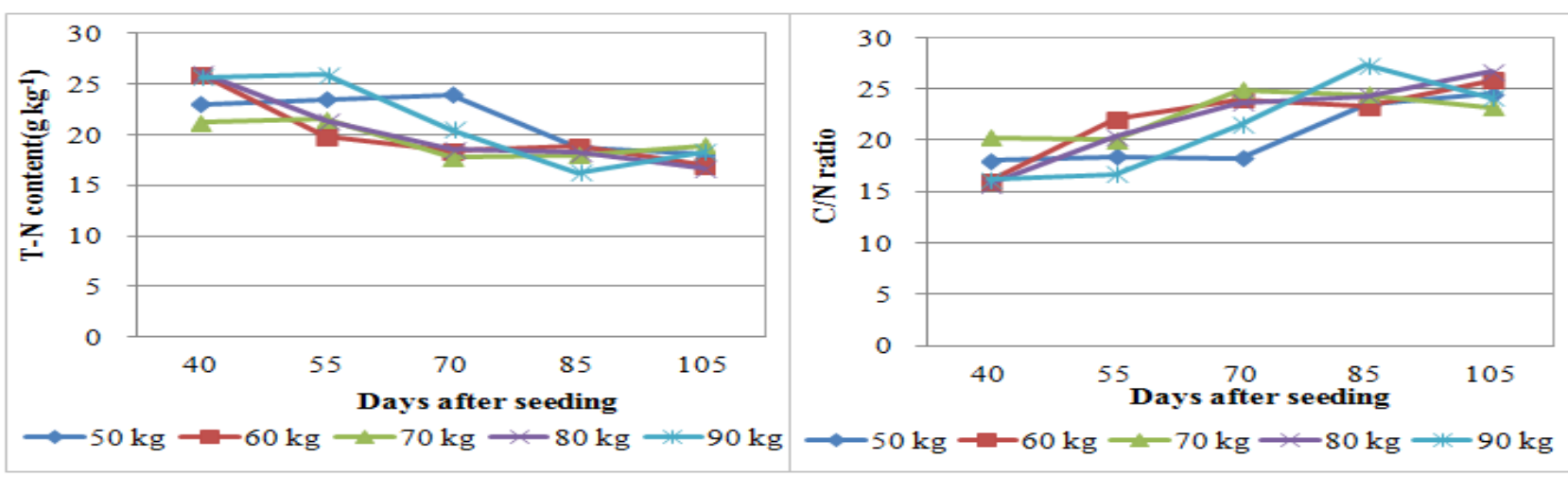

Fig. 6. The changes of total nitrogen (T-N) concentration (left) and $\mathrm{C} / \mathrm{N}$ ratio (right) of crotalaria according to the seeding rates and the harvest time.

Table 3. The chemical characteristics of above- and below-ground parts of crotalaria at the flowering time.

\begin{tabular}{|c|c|c|c|c|c|c|c|}
\hline Items & $\mathrm{T}-\mathrm{N}$ & $\mathrm{T}-\mathrm{C}$ & $\mathrm{CaO}$ & $\mathrm{MgO}$ & $\mathrm{K}_{2} \mathrm{O}$ & $\mathrm{P}_{2} \mathrm{O}_{5}$ & $\mathrm{C} / \mathrm{N}$ \\
\hline & ---- & - & 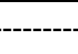 & $\mathrm{g} \mathrm{kg}^{-1}$ & ---- & - & - \\
\hline Above-ground part & 19.8 & 440.2 & 13.8 & 5.7 & 16.8 & 4.2 & 22.5 \\
\hline Below-ground part & 9.3 & 396.6 & 1.8 & 2.6 & 12.1 & 5.8 & 42.6 \\
\hline
\end{tabular}

것이 좋을 것으로 사료되었다. 더군다나 최근에 클로탈라리 아의 수요량이 증가하면서 종자가격이 점차 상승하고 있기 때문에 경영비 절감 차원에서도 클로탈라리아의 파종량은 $50 \mathrm{~kg} \mathrm{ha}{ }^{-1}$ 가 적당 할 것으로 판단되었다.

클로탈라리아의 화학적 특성 녹비작물 이용시기는 농 경지의 휴경기간과 녹비작물의 수량, 그리고 $\mathrm{CN}$ 율 등을 고 려하여 이루어지는데 녹비작물들은 대부분 개화기를 전후 로 토양에 환원하게 된다. 이는 대부분의 작물들이 개화기 를 거치면서 식물체의 경화로 줄기가 딱딱해지기 때문에 경 운이 어려워질 뿐만 아니라 CN율도 높아져 토양 환원 후 분해 시간이 길어지기 때문이다 (RDA, 2009; Song et. al., 2010). 클로탈라리아의 화학적 특성은 Table 3 과 같이 지상부 질소 함량 $(\mathrm{T}-\mathrm{N})$ 은 $19.8 \mathrm{~g} \mathrm{~kg}^{-1}$ 으로 지하부의 질소함량 $\left(9.3 \mathrm{~g} \mathrm{~kg}^{-1}\right)$ 보다 약 2.1 배가 높았다. 식물체 내의 질소함량은 여름용 두
과 녹비작물인 화이트클로버보다는 낮지만 세스바니아, 네 마황 (Crotalaria spectabilis), 레드클로버와 비슷한 함량이 었다 (RDA, 2009). 클로탈라리아의 탄소함량 $(\mathrm{T}-\mathrm{C})$ 는 지상 부와 지하부간에 차이가 없었으며 $\mathrm{C} / \mathrm{N}$ 율은 지상부는 22.5 , 지하부는 42.6 이었다. 토양에 환원된 유기물의 분해속도는 $\mathrm{CN}$ 율을 기준으로 평가하게 되는데 $\mathrm{CN}$ 율이 25 이상이면 분 해시간이 길기 때문에 녹비로 이용 할 경우 분해를 촉진하 기 위하여 미생물의 영양원인 질소비료를 추가 시용이 필요 하고 25미만이면 빨리 분해되어 질소나 다른 양분들이 무기 화되는데 걸리는 시간이 짧다고 하였다 (Daimon and Kotoura, 2000; Jeon et al., 2010; Mendonca and Schiavinato, 2005; Yang et al., 2009). 클로탈라리아의 탄질율은 지상부는 낮 으나 지하부가 높은 편인데 식물체의 비중을 볼 때 (Fig. 1) 지상부가 $90 \%$ 를 차지하기 때문에 녹비로 이용 할 때 분해는 용 이 할 것으로 판단되었다. 클로탈라리아 인산함량은 $4.2 \sim 5.8 \mathrm{~g}$ 
Table 4. The total nitrogen (T-N) contents of parts of crotalaria in the flowering time.

\begin{tabular}{cccccc}
\hline \hline \multirow{2}{*}{ Days after seeding } & \multirow{2}{*}{ Total plant } & \multicolumn{2}{c}{ below-ground part } & \multicolumn{3}{c}{ Above-ground part } \\
\cline { 3 - 5 } & & Root & Leaf & Stem & Flower \\
\hline & $-0 .-14.1 \mathrm{a}$ & $43.5 \mathrm{~b}$ & $13.0 \mathrm{a}$ & - \\
55 & $24.4 \mathrm{a}$ & $10.3 \mathrm{~b}$ & $46.0 \mathrm{a}$ & $11.4 \mathrm{a}$ & - \\
70 & $22.4 \mathrm{a}$ & $9.3 \mathrm{c}$ & $40.3 \mathrm{~d}$ & $9.9 \mathrm{~b}$ & - \\
85 & $19.8 \mathrm{~b}$ & $8.0 \mathrm{~d}$ & $42.3 \mathrm{c}$ & $9.9 \mathrm{~b}$ & $52.5 \mathrm{a}$ \\
105 & $18.0 \mathrm{~b}$ & $7.2 \mathrm{e}$ & $34.8 \mathrm{e}$ & $5.1 \mathrm{c}$ & $48.1 \mathrm{~b}$ \\
Average & $17.8 \mathrm{~b}$ & 13.4 & 41.4 & 8.8 & 50.3 \\
\hline
\end{tabular}

\rfloor Means in a column followed by the same letter are not significantly different at $\mathrm{p} \leq 0.05$ based on Duncan's multiple range test

$\mathrm{kg}^{-1}$ 이었고, 칼륨함량은 $12.1 \sim 16.8 \mathrm{~g} \mathrm{~kg}^{-1}$ 으로 지상부와 지 하부간에 차이가 적었다.

수확시기에 따른 클로탈라리아의 질소함량은 Table 4 와 같이 클로탈라리아 식물체 전체의 질소함량은 $20.5 \mathrm{~g} \mathrm{~kg}^{-1}$ 이었으며 부위별로는 줄기가 가장 낮았고 잎은 $41.4 \mathrm{~g} \mathrm{~kg}^{-1}$, 뿌리는 $13.4 \mathrm{~g} \mathrm{~kg}^{-1}$ 이었다. 수확시기별로 보면 줄기와 뿌리 의 질소함량은 수확시기가 늦을수록 점차 감소되었으며 잎 은 파종 후 55 일까지 증가되었다가 감소되었다. 잎과 줄기 모두 종자가 맺히는 파종 후 105 일에는 질소함량이 현저히 감 소되었다. 꽃의 질소함량은 $48.1 \mathrm{~g} \mathrm{~kg}^{-1} \sim 52.5 \mathrm{~g} \mathrm{~kg}^{-1}$ 으로 매 우 높았다. 이런 패턴을 보이는 것은 생육초기에는 식물체 가 영양생장을 위하여 잎과 줄기에 양분을 저장하는 반면 생식생장기에 들어서면 개화와 종자결실을 위하여 꽃에 양 분이 저장되었기 때문으로 사료되었다.

\section{클로탈라리아 파종량에 따른 질소함량과 $\mathbf{C} / \mathbf{N}$ 율 파} 종량에 따른 클로탈라리아의 질소함량과 $\mathrm{CN}$ 율은 Fig. 6 과 같이 클로탈라리아 지상부의 질소함량은 생육초기에는 21.2 $\sim 26.1 \mathrm{~g} \mathrm{~kg}^{-1}$ 이었으나 수확시기가 늦어질수록 점차 감소하 여 파종 후 105일에는 생육초기보다 약 $5 \sim 7 \mathrm{~g} \mathrm{~kg}^{-1}$ 이 낮았 다. 파종량에 따른 클로탈라리아 식물체의 질소함량은 뚜렷 한 차이를 보이지 않았으며 오히려 생육단계에 따른 질소함 량의 변이가 더 뚜렷하게 나타났다. $\mathrm{CN}$ 율은 식물체의 질소 함량과는 반대로 생육초기에는 낮은 경향이었으나 수확시 기가 늦어질수록 점차 증가되어 파종 후 105일에는 23 27 이었다. 식물체의 $\mathrm{CN}$ 율은 토양 미생물이 활동하는데 필요 한 질소와 탄소를 공급하여 미생물 활성을 알아보는 값으로 식물체의 $\mathrm{CN}$ 율이 25 미만이면 유기물의 분해가 빠르게 이 루어진다고 하였다 (Yang et. al., 2009). 클로탈라리아는 수확시기가 늦어질수록 질소함량은 감소되고 $\mathrm{CN}$ 율이 증가 되는 경향이었으나 $\mathrm{CN}$ 율이 25 이상으로 높지 않아 필요한 경우 토양 환원시기를 개화기 이후에 실시하여도 분해에는 문제가 없을 것으로 판단되었다.

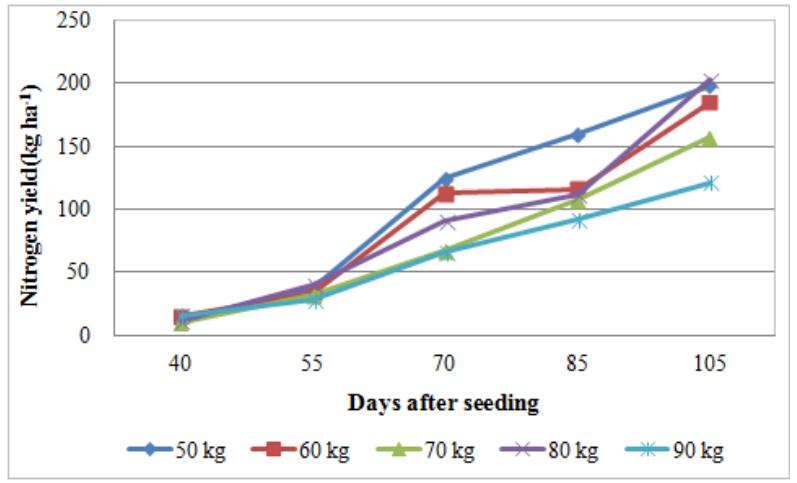

Fig. 7. The changes of nitrogen yield of crotalaria according to the seeding rates and the harvest time.

클로탈라리아 파종량에 따른 질소생산량 클로탈라리 아 파종량에 따른 질소생산량은 Fig. 7과 같이 수확시기가 늦어질수록 질소생산량은 증가하였으며 특히 파종 후 55 일 이후 급격히 증가되는 경향을 보여 105일에 121 203 kg ha-1 의 질소가 생산되었다. 파종량별로 보면 종자 파종량이 적 을수록 질소생산량은 더 많았다. 이는 클로탈라리아 건물수 량이 파종량이 적은 $50 \mathrm{~kg} \mathrm{ha}^{-1}$ 에서 많았고 (Fig. 3) 질소함 량은 파종량간에 차이가 적었기 때문으로 사료되며 또한 질 소함량이 높은 주당 엽수도 파종량이 적은 $50 \mathrm{~kg} \mathrm{ha}^{-1}$ 에서 많았기 때문이었다 (Table 4 참조). 이는 파종량을 많이 파 종하는 것보다는 적절한 양을 파종하면 식물체는 충분한 양 분공급과 햇빛을 통하여 잘 자라는 반면 파종량을 늘려 밀 식재배를 하면 종자가격도 많이 소요될 뿐만 아니라 식물체 간의 양분경합으로 오히려 건물수량이 떨어지기 때문에 이 용하는 목적에 맞게 적절한 양을 선택하는 것이 좋을 것으 로 판단되었다. 클로탈라리아를 100 일까지 재배할 경우에 는 대부분 작물의 표준시비량에 해당하는 질소량이 생산되 었으나 개화시인 50 일의 전후에 토양에 환원하면 클로탈라 리아의 질소 생산량이 낮아 대부분의 작물에서 화학비료의 추가 시용이 요구되었다. 


\section{Conclusion}

클로탈라리아는 콩과 녹비작물로 우리나라에서는 여름에 재배가 가능한 작물이다. 이 작물은 재배가 쉽고 파종 후 생 육이 빨라 녹비수량이 많을 뿐만 아니라 질소고정을 하기 때문에 여름용 녹비작물로 인기가 높아 재배면적이 증가되 고 있다. 이 클로탈라리아의 적정 파종량을 구명하기 위하 여 밭토양에 ha당 $50,60,70,80,90 \mathrm{~kg}$ 을 파종하여 녹비 수량과 질소생산량을 조사하였다. 클로탈라리아의 초장은 수확시기가 늦어질수록 증가하였으나 파종량에 따른 차이 는 보이지 않았으며 주당엽수는 수확시기가 늦어질수록 증 가하였으나 파종량이 증가할수록 감소하는 경향을 보였다. 클로탈라리아 지상부의 질소함량은 $19.8 \mathrm{~g} \mathrm{~kg}^{-1}$ 이었고, 탄 질율은 22.5 으며 지하부의 질소함량은 $9.3 \mathrm{~g} \mathrm{~kg}^{-1}$ 이었다. 수확시기에 따른 클로탈라리아의 생육 및 수량은 수확시기가 늦어질수록 증가되었으며 부위별로는 줄기, 잎, 뿌리, 꽃 순이 었다. 클로탈라리아의 부위별 질소함량은 꽃에서 $50.3 \mathrm{~g} \mathrm{~kg}^{-1}$ 로 가장 높았고 잎, 뿌리, 줄기 순이었다. 파종량에 따른 클 로탈라리아의 녹비수량은 파종량이 적은 $50 \mathrm{~kg} \mathrm{ha}^{-1}$ 구에서 가장 많았으며 파종량이 증가할수록 감소하는 경향이었고 질소생산량도 같은 경향을 보였다. 따라서 클로탈라리아의 이용시기, 녹비생산량과 질소생산량 등을 고려할 때 적정 파종량은 $50 \mathrm{~kg} \mathrm{ha}^{-1}$ 이 좋았으며 토양 환원 시기는 개화시 에 하는 것이 좋을 것으로 사료되었다.

\section{References}

Chaudhury, J., D.P. Singh, and S.K. Hazra, 1978, Sunn hemp. Central research institute for jute and allied fibers(ICAR); http;//assamagribusiness.nic.in/sunnhemp.pdf

Choi, H.S., K.H. Lim, Y. Lee, H.J. Jee, and J.L. Cho, 2011, Nutrient contribution as affected by ground cover treatments in a pear orchard, Kor. J. Weed Sci.

Cook, C.G., and G.A. White, 1996, Crotalaria juncea; A potential multi-purpose fiber crop. p.389 394. In; J. Janick (ed.). Progress in new crops. ASHS press,Arlington,VA.

Daimon, H., and S. Kotoura, 2000, Incorporation of crotalaria spectabilis grown at a high seeding rate inhibits the growth of the succeeding wheat crop. J.Agronomy and Crop Science 185, 137-144

Germani, G., and C. Plenchette, 2005, Potential of Crotalaria species as green manure crops for the management of pathogenic nematodes and beneficial mycorrhizal fungi, Plant and Soil January, Volume 266(1-2), pp. 333-342

Jeon W.T., K.Y. Seong, M.T. Kim, G.J. Oh, I.S. Oh, and U.G. Kang, 2010, Changes of soil physical properties by glomalin concentration and rice yield using different green manure crops in paddy, Korean J. Soil Sci. Fert. Vol 43(2):119-123.
Lee, I.B, S.B. Kang, and J.M. Park, 2008, Growth of Tomato and Nitrogen Balance in Soil by Soil Reducing of Crotalaria, Korean J. Soil Sci. Fert., vol. 41(1):190 in korea

Lee, Y., H.S. Choi, and S.M. Lee, 2012, Estimation of N- and P-Mineralization of Organic Materials under a Paddy Condition, Korean J. Intl. Agri., 24(3):299-302 .

Lim T.J., K.I. Kim, J.M. Park, 2012, The Use of Green Manure Crops as a Nitrogen Source for Lettuce and Chinese Cabbage Production in Greenhouse, Korean J. of Environmental Agriculture, vol. 31(3):212-216.

Mendonca, E.H.M. and M.A. Schiavinato. 2005. Growth of Crotalaria juncea L. supplied with mineral nitrogen. Braz. arch. biol.t echnol. vol. 48(2).

NIAST. 2000. Analytical methods of soil and plant. National Institute of Agricultural Science and Technology, RDA, Suwon, Korea.

Orwa, C., A. Mutua, R. Kindt, R. Jamnadass, A. Simons. 2009. Agroforestree database: a tree reference and selection guide version 4.0 (http://www.worldgroforestry.org/af/treedb/)

Rural Development Administration (RDA). 2003. Standard measurement and analysis in agricultural research and development, RDA, Suwon, Korea.

Rural Development Administration (RDA). 2009. Study of Environment-friendly Fertilizer Reduction using Green Manure Crops(4th), RDA, Suwon, Korea.

Song B.H., K.A. Lee, W.T. Jeon, M.T. Kim, H.S. Cho, I.S. Oh, C.G. Kim, and U.G. Kang, 2010, Effects of green manure crops of legume and gramineae on growth responses and yields in rice cultivation with respect to environment friendly agriculture, Korea J. Crop Sci. vol55(2):144-150.

Treadwell, D.D., and Alligood, M., 2007, Sunn hemp(Crotalaria juncea L.); A summer cover crop for Florida vegatable producers, University of Florida/IFAS, http;//edis.ifas.ufl.edu.

Wang, K.H., R. McSorley, R.N. Gallaher, 2003, Effect of Crotalaria juncea Amendment on Nematode Communities in Soil with Different Agricultural Histories 1, Journal of Nematology Vol. 35(3):294-301.

Wang, K.H., R. McSorley, A. Marshall, R.N. Gallaher, 2006, Influence of organic Crotalaria juncea hay and ammonium nitrate fertilizers on soil nematode communities, Applied Soil Ecology Volume 31(3):186-198

Yang C.H., J.H. Ryu, T.K. Kim, S.B. Lee, J.D. Lee, N.H. Beak, W.Y. Choi, and S.J. Kim, 2009, Effect of green manure crops incorporation with rice cultivation on soil fertility improvement in paddy field, Korean J. Soil Sci. Fert. Vol. 42(5):371-378.

Yang S.K., Y.W. Seo, Y.S. Lee, H.W. Kim, K.C. Ma, K.H. Lim, H.J. Kim, J.G. Kim, and W.J. Jung, 2011, Effect of green manure crops on red-pepper yield and soil physic-chemical properties in the vinyl house, Korean J. of Organic agriculture. vol. 19(2):215-228. 